\title{
Effects of Organic and Inorganic Materials on Soil Acidity and Phosphorus Availability in a Soil Incubation Study
}

\author{
P. A. Opala, ${ }^{1}$ J. R. Okalebo, ${ }^{2}$ and C. O. Othieno ${ }^{2}$ \\ ${ }^{1}$ Department of Horticulture, Kabianga University College, P.O. Box 2030, Kericho, Kenya \\ ${ }^{2}$ Department of Soil Science, Moi University, P.O. Box 1125, Eldoret, Kenya
}

Correspondence should be addressed to P. A Opala, ptropala@yahoo.com

Received 5 April 2012; Accepted 10 May 2012

Academic Editors: R. Burt, T. E. Fenton, and J. Hatfield

Copyright (C 2012 P. A. Opala et al. This is an open access article distributed under the Creative Commons Attribution License, which permits unrestricted use, distribution, and reproduction in any medium, provided the original work is properly cited.

\begin{abstract}
We tested the effects of two organic materials (OMs) of varying chemical characteristics that is, farmyard manure (FYM) and Tithonia diversifolia (tithonia), when applied alone or in combination with three inorganic $\mathrm{P}$ sources, that is, triple superphosphate (TSP), Minjingu phosphate rock (MPR), and Busumbu phosphate rock (BPR) on soil pH, exchangeable acidity, exchangeable Al, and $\mathrm{P}$ availability in an incubation study. FYM and tithonia increased the soil $\mathrm{pH}$ and reduced the exchangeable acidity and $\mathrm{Al}$ in the short term, but the inorganic $\mathrm{P}$ sources did not significantly affect these parameters. The effectiveness of the inorganic $\mathrm{P}$ sources in increasing $\mathrm{P}$ availability followed the order, TSP $>$ MPR $>$ BPR, while among the OMs, FYM was more effective than tithonia. There was no evidence of synergism in terms of increased available $\mathrm{P}$ when organic and inorganic $\mathrm{P}$ sources were combined. The combination of OMs with inorganic P fertilizers may, however, have other benefits associated with integrated soil fertility management.
\end{abstract}

\section{Introduction}

Soil acidity and phosphorus deficiencies limit crop production in many tropical soils [1]. Lime and inorganic phosphate fertilizers are used in developed countries to remedy these problems. However, due to increasing costs and unavailability when needed, their use among smallholder farmers in developing countries is not widespread. This coupled with concerns for environmental protection and sustainability has renewed interest in the use of alternative cheaper locally available materials. The use of phosphate rocks (PR) and organic materials has in particular received increased attention in recent years in eastern Africa [2-4]. In addition to provision of $\mathrm{P}, \mathrm{PRs}$ have $\mathrm{Ca}$ and $\mathrm{Mg}$ which makes them assume a significant role as a potential tool for sustaining soil productivity by reducing soil acidity through its liming effect [5]. Although most OMs are low in P, they can influence soil parameters such as soil $\mathrm{pH}$, exchangeable $\mathrm{Al}$, and $\mathrm{Ca}$, which greatly influence crop growth [3].

There are a number of PR deposits of variable reactivity in eastern Africa which, however, differ greatly in their suitability as sources of $\mathrm{P}$ in P-deficient soils [6]. The most promising of these PRs are Minjingu in northern Tanzania and Busumbu in eastern Uganda [7], but their low solubility makes them unsuitable for direct application [1]. Techniques aiming to increase the solubility of BPR through blending with soluble phosphate fertilizers such as TSP or partial acidulation are likely not to have positive effects in terms of increasing $\mathrm{P}$ availability and uptake by plants $[1,8]$. Enhancing the solubility of PRs by combining them with OMs has been tried in western Kenya, but there is no consensus as to whether or not these combinations enhance $\mathrm{P}$ availability [9]. Interactions of OMs with inorganic P nutrient inputs and their effect on $\mathrm{P}$ availability and soil acidity therefore merit further study. The objective of this study was to investigate the effect of inorganic phosphorus sources (TSP, MPR, and BPR) when applied alone or in combination with OMs (tithonia or FYM) on soil $\mathrm{pH}$, exchangeable acidity, exchangeable $\mathrm{Al}$, and $\mathrm{P}$ availability acid $\mathrm{P}$-deficient soils.

1.1. Materials and Methods. The study was conducted from April to July 2008 at Moi University, using soils collected at 
TABLE 1: Initial surface $(0-15 \mathrm{~cm})$ soil properties.

\begin{tabular}{|c|c|c|}
\hline Parameter & Bukura & Kakamega \\
\hline $\mathrm{pH}\left(\mathrm{H}_{2} \mathrm{O}\right)(1: 2.5)$ & 4.80 & 5.10 \\
\hline Exchangeable acidity $\left(\mathrm{cmol}_{\mathrm{c}} \mathrm{kg}^{-1}\right)$ & 0.88 & 0.35 \\
\hline Exchangeable $\mathrm{Al}\left(\mathrm{cmol}_{\mathrm{c}} \mathrm{kg}^{-1}\right)$ & 0.63 & 0.13 \\
\hline $\mathrm{Ca}$ & 1.94 & 2.1 \\
\hline $\mathrm{Mg}$ & 1.01 & 1.8 \\
\hline $\mathrm{K}$ & 0.12 & 0.2 \\
\hline ECEC & 3.95 & 4.85 \\
\hline $\mathrm{Al}$ saturation (\%) & 22 & 7.2 \\
\hline Organic C (\%) & 3.2 & 2.7 \\
\hline Total N (\%) & 0.3 & 0.3 \\
\hline $\mathrm{C}: \mathrm{N}$ ratio & 10.6 & 9.0 \\
\hline Total P (\%) & 0.04 & 0.03 \\
\hline Olsen P $\left(\mathrm{mg} \mathrm{kg}^{-1}\right)$ & 5.6 & 2.5 \\
\hline$P$ sorbed at $\left(0.2 \mathrm{mg} \mathrm{kg}^{-1}\right)$ & 260 & 45 \\
\hline \multicolumn{3}{|l|}{ Texture (\%) } \\
\hline Sand & 52 & 54 \\
\hline Silt & 18 & 28 \\
\hline Clay & 30 & 18 \\
\hline Soil classification (FAO System) & $\begin{array}{l}\text { Orthic } \\
\text { ferralsol }\end{array}$ & $\begin{array}{c}\text { Ferralic } \\
\text { cambisols }\end{array}$ \\
\hline
\end{tabular}

two sites in western Kenya which were selected on the basis of contrasting characteristics (Table 1).

Surface soil $(0-15 \mathrm{~cm})$ samples were randomly taken from each site and thoroughly mixed by hand to produce one homogenous sample per site. Two hundred gram samples of air-dried soil $(<2 \mathrm{~mm})$ from each site were weighed into plastic polythene bags which were kept in upright positions in a laboratory. Finely ground $(<1 \mathrm{~mm})$ tithonia, FYM (obtained from cattle), BPR, MPR, or TSP were added to the soils according to the treatments given in Table 2 and thoroughly mixed. The treatments were arranged in a completely randomized design with three replications. The procedure used by [10] was used with slight modifications. This involved incubation of the samples for 16 weeks at room temperature. Moisture content in the soil samples was adjusted to field capacity and maintained at that level during the entire period of incubation. Soils were sampled twice from each treatment, that is, at 4 and 16 weeks after the start of the incubation (WAI), air-dried, and sieved before being analyzed.

1.2. Analyses of Soils and the Organic Materials. The soils and the OMs were analyzed using the following methods; organic $\mathrm{C}$ was determined by Walkley and Black sulphuric acid-dichromate digestion followed by back titration with ferrous ammonium sulphate [11]. Total $\mathrm{N}$ and $\mathrm{P}$ in the soils were determined by digesting $0.3 \mathrm{~g}$ of the soil sample in a mixture of Se, $\mathrm{LiSO}_{4}, \mathrm{H}_{2} \mathrm{O}_{2}$, and concentrated $\mathrm{H}_{2} \mathrm{SO}_{4}$ [12]. The $\mathrm{N}$ and $\mathrm{P}$ contents in the digests were determined colorimetrically. Total soluble polyphenols in tithonia and FYM were determined by the Folin-Ciocalteau method [11], while the lignin content was determined using the acid detergent fiber (ADF) method as described by [11]. Soil pH was determined using a glass electrode $\mathrm{pH}$ meter at $1: 2.5$ soil : water ratio [13]. The basic cations ( $\mathrm{Ca}, \mathrm{Mg}$, and $\mathrm{K}$ ) were extracted using ammonium acetate at $\mathrm{pH} 7$ [13]. Exchangeable $\mathrm{Ca}$ and $\mathrm{Mg}$ in the extract were determined using atomic absorption spectrophotometry, and exchangeable K by flame photometry. Exchangeable acidity and exchangeable $\mathrm{Al}$ were extracted using unbuffered $1 \mathrm{M} \mathrm{KCl} \mathrm{[11].}$

\section{Results}

2.1. Characteristics of the Organic Materials Used in the Study. Tithonia contained higher amounts of $\mathrm{C}, \mathrm{N}, \mathrm{Ca}, \mathrm{Mg}$, and $\mathrm{K}$ than $\mathrm{FYM}$, but its total $\mathrm{P}$ content and $\mathrm{pH}$ were lower (Table 3). The $\mathrm{C}: \mathrm{N}$ ratios of tithonia and FYM were 13.5 and 20 , respectively, and a net mineralization of $\mathrm{N}$ would therefore be expected to occur from both OMs [14]. The $\mathrm{C}: \mathrm{P}$ ratios were 140 for tithonia and 90 for FYM. Tithonia had low $(<15 \%)$ while FYM had high $(>15 \%)$ lignin content. Both OMs had low polyphenol content $(<4 \%)$. According to the criteria proposed by [14], tithonia would be a highquality OM, while FYM would be a medium-quality OM.

2.2. Effect of Organic and Inorganic Amendments on Soil pH. Results for soil $\mathrm{pH}$ as affected by the treatments for the Bukura and Kakamega soils are presented in Tables 4 and 5 , respectively. Averaged across all treatments, the soil $\mathrm{pH}$ at Bukura at 4 WAI (4.91) and 16 WAI (4.27) was lower than at Kakamega at similar times (5.31 and 4.65, resp.). The $\mathrm{pH}$ of the soils at 4 WAI was lowest for the control treatment and highest for tithonia applied in combination with MPR for both soil types. All the tithonia treatments (applied alone or in combination with the inorganic inputs), apart from Tithonia $\left(20 \mathrm{~kg} \mathrm{Pha}^{-1}\right)$, showed a significant increase in $\mathrm{pH}$ above the control treatment at 4 WAI for the Bukura soil. All the other treatments had no significant effect on soil $\mathrm{pH}$ at this time for this soil. At Kakamega, all the tithonia treatments with the exception of Tithonia $\left(20 \mathrm{~kg} \mathrm{Pha}^{-1}\right)+$ TSP $\left(40 \mathrm{~kg} \mathrm{Pha}^{-1}\right)$ and Tithonia $\left(20 \mathrm{~kg} \mathrm{Pha}^{-1}\right)$ significantly increased the soil $\mathrm{pH}$ above that of the control. FYM when applied alone or in combination with the inorganic $\mathrm{P}$ sources generally increased soil $\mathrm{pH}$ of both soil types, although statistical significance was not always attained. There was no significant treatment effect on soil $\mathrm{pH}$ at 16 WAI for soils from both sites.

Averaged across the three inorganic $\mathrm{P}$ sources, the soil $\mathrm{pH}$ followed the trend Tithonia $>$ FYM $>$ no OM at both sites. Averaged across the OMs, MPR gave a significantly higher soil $\mathrm{pH}$ than TSP and BPR at both sites at 4 WAI. There was a decline in soil $\mathrm{pH}$ in all the treatments at 16 WAI compared to 4 WAI for both soil types. Averaged across all the treatments, the $\mathrm{pH}$ of the Bukura and Kakamega soils declined by 0.67 and 0.64 units, respectively. In general, the acidification over time was more pronounced with the tithonia treatments at both sites. 
TABLE 2: The experimental treatments.

\begin{tabular}{|c|c|c|c|c|}
\hline \multirow{2}{*}{ Treatment } & \multirow{2}{*}{ P source } & \multicolumn{3}{|c|}{$\mathrm{P}$ rate $\left(\mathrm{kg} \mathrm{ha}^{-1}\right)$} \\
\hline & & From organics & From inorganics & Total P \\
\hline (1) Control & - & 0 & 0 & 0 \\
\hline (2) Tithonia $\left(60 \mathrm{~kg} \mathrm{P} \mathrm{ha}^{-1}\right)$ & Tithonia & 60 & 0 & 60 \\
\hline (3) FYM (60 kg P ha-1) & FYM & 60 & 0 & 60 \\
\hline (4) MPR (60 kg P ha $\left.{ }^{-1}\right)$ & MPR & 0 & 60 & 60 \\
\hline (5) TSP $\left(60 \mathrm{~kg} \mathrm{P} \mathrm{ha}^{-1}\right)$ & TSP & 0 & 60 & 60 \\
\hline (6) BPR (60 kg P ha-1) & BPR & 0 & 60 & 60 \\
\hline (7) Tithonia $\left(20 \mathrm{~kg} \mathrm{P} \mathrm{ha}^{-1}\right)+$ MPR $\left(40 \mathrm{~kg} \mathrm{P} \mathrm{ha}^{-1}\right)$ & Tithonia and MPR & 20 & 40 & 60 \\
\hline (8) Tithonia $\left(20 \mathrm{~kg} \mathrm{P} \mathrm{ha}^{-1}\right)+\left(\right.$ TSP $\left.40 \mathrm{~kg} \mathrm{P} \mathrm{ha}^{-1}\right)$ & Tithonia and TSP & 20 & 40 & 60 \\
\hline (9) Tithonia $\left(20 \mathrm{~kg} \mathrm{P} \mathrm{ha}^{-1}\right)+\mathrm{BPR}\left(40 \mathrm{~kg} \mathrm{P} \mathrm{ha}^{-1}\right)$ & Tithonia and BPR & 20 & 40 & 60 \\
\hline (10) FYM (20 kg P ha-1) + MPR $\left(40 \mathrm{~kg} \mathrm{P} \mathrm{ha}^{-1}\right)$ & FYM and MPR & 20 & 40 & 60 \\
\hline (11) FYM (20 kg P ha-1) + TSP (40 kg P ha-1) & FYM and TSP & 20 & 40 & 60 \\
\hline (12) FYM (20 kg P ha-1) + BPR (40 kg P ha-1) & FYM and BPR & 20 & 40 & 60 \\
\hline (13) Tithonia (20 kg P ha-1) & Tithonia & 20 & 0 & 20 \\
\hline (14) FYM (20 kg P ha-1) & FYM & 20 & 0 & 20 \\
\hline (15) MPR (40 kg P ha-1) & MPR & 0 & 40 & 40 \\
\hline (16) TSP (40 kg P ha-1) & TSP & 0 & 40 & 40 \\
\hline (17) BPR $\left(40 \mathrm{~kg} \mathrm{P} \mathrm{ha}^{-1}\right)$ & $\mathrm{BPR}$ & 0 & 40 & 40 \\
\hline
\end{tabular}

FYM: farmyard manure; TSP: triple superphosphate; MPR: Minjingu phosphate rock; BPR: Busumbu phosphate rock.

TABLE 3: Average chemical composition of tithonia and farmyard manure used in the study over the three seasons.

\begin{tabular}{lccccccccccc}
\hline & m.c. & $\% \mathrm{C}$ & $\% \mathrm{~N}$ & $\mathrm{C}: \mathrm{N}$ ratio & $\% \mathrm{P}$ & $\% \mathrm{Ca}$ & $\% \mathrm{Mg}$ & $\% \mathrm{~K}$ & $\mathrm{pH}$ & \% Lig & \% Poly \\
\hline Tithonia & $80 \%$ & 42 & 3.1 & 13.5 & 0.30 & 2.0 & 0.6 & 4.1 & 6.5 & 13 & 3.17 \\
FYM & $30 \%$ & 36 & 1.8 & 20.0 & 0.40 & 0.9 & 0.5 & 2.2 & 7.7 & 21 & 0.84 \\
\hline
\end{tabular}

FYM: farmyard manure; lig.: lignin; poly.: polyphenol; m.c.: moisture content.

TABLE 4: Effect of organic and inorganic materials on soil $\mathrm{pH}$, exchangeable acidity and exchangeable $\mathrm{Al}$ for the Bukura soils in the incubation study.

\begin{tabular}{|c|c|c|c|c|c|c|c|c|c|}
\hline \multirow{2}{*}{ Treatment } & \multicolumn{3}{|c|}{$\mathrm{pH}$} & \multicolumn{3}{|c|}{ Exchangeable acidity $\left(\mathrm{cmol} \mathrm{kg}^{-1}\right)$} & \multicolumn{3}{|c|}{ Exchangeable $\mathrm{Al}\left(\mathrm{cmol} \mathrm{kg}^{-1}\right)$} \\
\hline & $4 \mathrm{WAI}$ & $16 \mathrm{WAI}$ & $\Delta \mathrm{pH}$ & 4 WAI & 16 WAI & $\Delta$ ex. acidity & 4 WAI & $16 \mathrm{WAI}$ & $\Delta$ ex. Al \\
\hline (1) Control & 4.63 & 4.24 & -0.39 & 0.89 & 0.87 & -0.02 & 0.63 & 0.62 & -0.01 \\
\hline (2) Tithonia (60 kg P ha-1) & 5.43 & 4.28 & -1.15 & 0.31 & 0.48 & 0.17 & 0.16 & 0.17 & 0.01 \\
\hline (3) FYM (60 kg P ha-1) & 4.78 & 4.26 & -0.52 & 0.66 & 0.77 & 0.11 & 0.42 & 0.49 & 0.07 \\
\hline (4) MPR (60 kg P ha-1) & 4.84 & 4.31 & -0.53 & 0.68 & 0.81 & 0.13 & 0.45 & 0.61 & 0.16 \\
\hline (5) TSP (60 kg P ha-1) & 4.68 & 4.25 & -0.43 & 0.79 & 0.84 & 0.05 & 0.67 & 0.59 & -0.08 \\
\hline (6) BPR (60 kg P ha-1) & 4.76 & 4.28 & -0.48 & 0.91 & 0.83 & -0.08 & 0.54 & 0.61 & 0.07 \\
\hline (7) Tithonia $\left(20 \mathrm{~kg} \mathrm{P} \mathrm{ha}^{-1}\right)+\mathrm{MPR}\left(40 \mathrm{~kg} \mathrm{P} \mathrm{ha}^{-1}\right)$ & 5.67 & 4.38 & -1.29 & 0.52 & 0.61 & 0.09 & 0.21 & 0.37 & 0.16 \\
\hline (8) Tithonia $\left(20 \mathrm{~kg} \mathrm{P} \mathrm{ha}^{-1}\right)+\left(\right.$ TSP $\left.40 \mathrm{~kg} \mathrm{P} \mathrm{ha}^{-1}\right)$ & 5.39 & 4.44 & -0.96 & 0.53 & 0.65 & 0.12 & 0.25 & 0.47 & 0.22 \\
\hline (9) Tithonia $\left(20 \mathrm{~kg} \mathrm{P} \mathrm{ha}^{-1}\right)+\mathrm{BPR}\left(40 \mathrm{~kg} \mathrm{P} \mathrm{ha}^{-1}\right)$ & 5.25 & 4.28 & -0.97 & 0.41 & 0.65 & 0.24 & 0.21 & 0.53 & 0.32 \\
\hline (10) FYM (20 kg P ha-1) + MPR (40 kg P ha-1) & 4.84 & 4.25 & -0.59 & 0.61 & 0.79 & 0.18 & 0.41 & 0.60 & 0.19 \\
\hline (11) FYM (20 kg P ha-1) + TSP (40 kg P ha-1) & 4.81 & 4.18 & -0.63 & 0.77 & 0.79 & 0.02 & 0.47 & 0.65 & 0.18 \\
\hline (12) FYM (20 kg P ha-1) + BPR (40 kg P ha-1) & 4.72 & 4.28 & -0.44 & 0.77 & 0.83 & 0.06 & 0.55 & 0.65 & 0.10 \\
\hline (13) Tithonia $\left(20 \mathrm{~kg} \mathrm{P} \mathrm{ha}{ }^{-1}\right)$ & 4.75 & 4.23 & -0.52 & 0.66 & 0.82 & 0.16 & 0.32 & 0.55 & 0.23 \\
\hline (14) FYM (20 kg P ha-1) & 4.76 & 4.29 & -0.47 & 0.71 & 0.83 & 0.12 & 0.48 & 0.65 & 0.17 \\
\hline (15) MPR (40 kg P ha-1) & 4.82 & 4.35 & -0.47 & 0.73 & 0.81 & 0.08 & 0.47 & 0.60 & 0.13 \\
\hline (16) TSP (40 kg P ha-1) & 4.73 & 4.18 & -0.55 & 0.83 & 0.90 & 0.07 & 0.57 & 0.71 & 0.14 \\
\hline (17) BPR (40 kg P ha-1) & 4.70 & 4.17 & -0.53 & 0.84 & 0.95 & 0.11 & 0.58 & 0.68 & 0.10 \\
\hline SED & 0.14 & N.S. & & 0.11 & 0.07 & & 0.10 & 0.07 & \\
\hline $\mathrm{CV} \%$ & 3.50 & & & 18.9 & 11.5 & & 27.5 & 11.50 & \\
\hline
\end{tabular}

WAI: weeks after incubation; FYM: farmyard manure; TSP: triple superphosphate; MPR: Minjingu phosphate rock; BPR: Busumbu phosphate rock; N.S.: not significant; SED: standard error of difference between means; Ex: exchangeable. 
TABLE 5: Effect of organic and inorganic materials on soil pH, exchangeable acidity, and exchangeable Al for the Kakamega soils in the incubation study.

\begin{tabular}{|c|c|c|c|c|c|c|c|c|c|}
\hline \multirow{2}{*}{ Treatment } & \multicolumn{3}{|c|}{$\mathrm{pH}$} & \multicolumn{3}{|c|}{ Exchangeable acidity $\left(\mathrm{cmol} \mathrm{kg}^{-1}\right)$} & \multicolumn{3}{|c|}{ Exchangeable $\mathrm{Al}\left(\mathrm{cmol} \mathrm{kg}^{-1}\right)$} \\
\hline & $4 \mathrm{WAI}$ & $16 \mathrm{WAI}$ & $\Delta \mathrm{pH}$ & $4 \mathrm{WAI}$ & $16 \mathrm{WAI}$ & $\Delta$ ex. acidity & $4 \mathrm{WAI}$ & $16 \mathrm{WAI}$ & $\Delta$ ex. Al \\
\hline (1) Control & 5.16 & 4.67 & -0.49 & 0.24 & 0.28 & 0.04 & 0.08 & 0.09 & 0.01 \\
\hline (2) Tithonia $\left(60 \mathrm{~kg} \mathrm{P} \mathrm{ha}^{-1}\right)$ & 5.41 & 4.35 & -1.06 & 0.21 & 0.23 & 0.02 & 0.01 & 0.00 & -0.01 \\
\hline (3) FYM (60 kg P ha-1) & 5.36 & 4.71 & -0.65 & 0.21 & 0.24 & 0.03 & 0.01 & 0.00 & -0.01 \\
\hline (4) MPR (60 kg P ha-1) & 5.34 & 4.75 & -0.59 & 0.24 & 0.27 & 0.03 & 0.03 & 0.00 & -0.03 \\
\hline (5) TSP (60 kg P ha-1) & 5.20 & 4.73 & -0.47 & 0.25 & 0.26 & 0.01 & 0.06 & 0.06 & 0.00 \\
\hline (6) BPR (60 kg P ha-1) & 5.20 & 4.73 & -0.47 & 0.32 & 0.29 & -0.03 & 0.10 & 0.08 & -0.02 \\
\hline (7) Tithonia $\left(20 \mathrm{~kg} \mathrm{P} \mathrm{ha}^{-1}\right)+\operatorname{MPR}\left(40 \mathrm{~kg} \mathrm{P} \mathrm{ha}^{-1}\right)$ & 5.77 & 4.75 & -1.02 & 0.21 & 0.21 & 0.00 & 0.03 & 0.00 & -0.03 \\
\hline (8) Tithonia $\left(20 \mathrm{~kg} \mathrm{P} \mathrm{ha}^{-1}\right)+\left(\right.$ TSP $\left.40 \mathrm{~kg} \mathrm{P} \mathrm{ha}^{-1}\right)$ & 5.32 & 4.61 & -0.71 & 0.25 & 0.25 & 0.00 & 0.04 & 0.00 & -0.04 \\
\hline (9) Tithonia $\left(20 \mathrm{~kg} \mathrm{P} \mathrm{ha}^{-1}\right)+\mathrm{BPR}\left(40 \mathrm{~kg} \mathrm{P} \mathrm{ha}^{-1}\right)$ & 5.39 & 4.38 & -1.01 & 0.24 & 0.31 & 0.07 & 0.05 & 0.00 & -0.05 \\
\hline (10) FYM (20 kg P ha $\left.{ }^{-1}\right)+$ MPR (40 kg P ha-1) & 5.36 & 4.82 & -0.54 & 0.23 & 0.25 & 0.02 & 0.03 & 0.00 & -0.03 \\
\hline (11) FYM $\left(20 \mathrm{~kg} \mathrm{P} \mathrm{ha}^{-1}\right)+\mathrm{TSP}\left(40 \mathrm{~kg} \mathrm{P} \mathrm{ha}^{-1}\right)$ & 5.33 & 4.74 & -0.59 & 0.24 & 0.27 & 0.03 & 0.02 & 0.03 & 0.01 \\
\hline (12) FYM (20 kg P ha $\left.{ }^{-1}\right)+$ BPR $\left(40 \mathrm{~kg} \mathrm{P} \mathrm{ha}^{-1}\right)$ & 5.36 & 4.61 & -0.75 & 0.24 & 0.28 & 0.04 & 0.02 & 0.04 & 0.02 \\
\hline (13) Tithonia $\left(20 \mathrm{~kg} \mathrm{P} \mathrm{ha}^{-1}\right)$ & 5.28 & 4.33 & -0.95 & 0.23 & 0.24 & 0.01 & 0.07 & 0.00 & -0.07 \\
\hline (14) FYM (20 kg P ha-1) & 5.21 & 4.68 & -0.53 & 0.24 & 0.26 & 0.02 & 0.02 & 0.00 & -0.02 \\
\hline (15) MPR (40 kg P ha-1) & 5.33 & 4.78 & -0.55 & 0.23 & 0.27 & 0.04 & 0.04 & 0.00 & -0.04 \\
\hline (16) TSP (40 kg P ha-1) & 5.20 & 4.70 & -0.50 & 0.25 & 0.29 & 0.04 & 0.07 & 0.00 & -0.07 \\
\hline (17) BPR (40 kg P ha-1) & 5.21 & 4.68 & -0.53 & 0.28 & 0.31 & 0.03 & 0.08 & 0.08 & 0.00 \\
\hline SED & 0.10 & N.S. & & N.S. & 0.014 & & N.S. & 0.018 & \\
\hline $\mathrm{CV} \%$ & 2.0 & & & & 5.6 & & & 40.00 & \\
\hline
\end{tabular}

WAI: weeks after incubation; FYM: farmyard manure; TSP: triple superphosphate; MPR: Minjingu phosphate rock; BPR: Busumbu phosphate rock; N.S.: not significant; SED: standard error of difference between means; Ex: exchangeable.

2.3. Exchangeable Acidity and Exchangeable Aluminum. At 4 WAI, tithonia when applied alone or in combination with the inorganic P sources significantly reduced the exchangeable acidity with respect to the control for the Bukura soil (Table 4). The largest reduction (65\%) at this sampling time was obtained with tithonia applied at a rate of $60 \mathrm{~kg} \mathrm{P} \mathrm{ha}^{-1}$. FYM also significantly reduced exchangeable acidity at 4 WAI, but only when it was applied at rate of $60 \mathrm{~kg} \mathrm{Pha}^{-1}$ $(26 \%)$ or in combination with MPR (31\%). There was generally an increase in exchangeable acidity in the soils sampled at 16 WAI compared to those at 4 WAI. At this time (16 WAI), all the tithonia treatments, other than tithonia $\left(20 \mathrm{~kg} \mathrm{P} \mathrm{ha}^{-1}\right)$, gave significant reduction in the exchangeable acidity with respect to the control at Bukura. The inorganic $\mathrm{P}$ sources did not significantly reduce the exchangeable acidity at both sampling times at Bukura although the MPR treatments had generally lower levels of exchangeable acidity than TSP or BPR.

There were no significant treatment effects on exchangeable acidity for the Kakamega soil at 4 WAI (Table 5). However, at $16 \mathrm{WAI}$, all the treatments with tithonia applied alone or in combination with inorganic $\mathrm{P}$ sources, except tithonia $\left(20 \mathrm{kgPha}^{-1}\right)+\mathrm{BPR}\left(40 \mathrm{kgPha}^{-1}\right)$, significantly reduced the exchangeable acidity at this site. FYM, when applied alone at $60 \mathrm{~kg} \mathrm{P} \mathrm{ha}^{-1}$ or in combination with MPR, also significantly reduced exchangeable acidity but not when applied at $20 \mathrm{kgPha}^{-1}$ or in combination with TSP or BPR. The inorganic P sources had no significant effect on exchangeable acidity when applied alone at 16 WAI at Kakamega (Table 5).

The exchangeable $\mathrm{Al}$ trends among the treatments were generally similar to those of exchangeable acidity for the Bukura soil, at both sampling times (Table 4). The Kakamega soil showed wide variations especially in the samples taken at 16 WAI in which exchangeable Al could not be detected in several treatments. When averaged across the three inorganic $\mathrm{P}$ sources, tithonia gave significantly lower exchangeable acidity and exchangeable Al levels compared to FYM and no OM. The effect of inorganic $\mathrm{P}$ sources on exchangeable acidity and exchangeable Al was not significant at Bukura, but at Kakamega, MPR had significantly lower amounts of exchangeable acidity than TSP and BPR at 16 WAI. Although FYM gave lower exchangeable acidity and exchangeable $\mathrm{Al}$ levels than when no OM was applied at both sampling times at Bukura, these differences were not statistically significant.

There was a strong significant negative correlation between the soil $\mathrm{pH}$ with both the exchangeable acidity $\left(r^{2}=\right.$ $0.74 ; P<0.001)$ and exchangeable aluminum $\left(r^{2}=0.73\right.$; $P<0.001)$ at $4 \mathrm{WAI}$ at Bukura. At $16 \mathrm{WAI}$, there was also a significant but weak correlation between the soil $\mathrm{pH}$ and exchangeable acidity $\left(r^{2}=0.34 ; P<0.05\right)$, but the correlation between soil $\mathrm{pH}$ and exchangeable $\mathrm{Al}$ was not significant at this time for the Bukura soil. At Kakamega, there was no significant correlation between the soil $\mathrm{pH}$ and exchangeable acidity or exchangeable $\mathrm{Al}$ at both sampling times. 
TABLE 6: Effect of organic and inorganic $\mathrm{P}$ amendments on Olsen $\mathrm{P}\left(\mathrm{mg} \mathrm{P} \mathrm{kg}^{-1}\right)$ at Bukura and Kakamega in the laboratory incubation study.

\begin{tabular}{|c|c|c|c|c|c|c|}
\hline \multirow{2}{*}{ Treatment } & \multicolumn{3}{|c|}{ Bukura } & \multicolumn{3}{|c|}{ Kakamega } \\
\hline & $4 \mathrm{WAI}$ & $16 \mathrm{WAI}$ & $\Delta$ Olsen $\mathrm{P}$ & $4 \mathrm{WAI}$ & $16 \mathrm{WAI}$ & $\Delta$ Olsen $\mathrm{P}$ \\
\hline (1) Control & 7.3 & 8.9 & 1.6 & 3.2 & 4.3 & 1.1 \\
\hline (2) Tithonia $\left(60 \mathrm{~kg} \mathrm{P} \mathrm{ha}^{-1}\right)$ & 13.1 & 14.7 & 1.6 & 8.2 & 9.6 & 1.4 \\
\hline (3) FYM (60 kg P ha $\left.{ }^{-1}\right)$ & 16.0 & 16.5 & 0.5 & 9.5 & 10.0 & 0.5 \\
\hline (4) MPR (60 kg P ha-1) & 13.4 & 16.3 & 2.9 & 6.9 & 8.0 & 1.1 \\
\hline (5) TSP (60 kg P ha-1) & 18.2 & 17.7 & -0.5 & 9.8 & 10.1 & 0.3 \\
\hline (6) BPR (60 kg P ha-1) & 11.0 & 11.5 & 0.5 & 4.5 & 6.0 & 1.5 \\
\hline (7) Tithonia $\left(20 \mathrm{~kg} \mathrm{P} \mathrm{ha}^{-1}\right)+\mathrm{MPR}\left(40 \mathrm{~kg} \mathrm{P} \mathrm{ha}^{-1}\right)$ & 14.1 & 13.9 & -0.2 & 7.9 & 6.3 & -1.6 \\
\hline (8) Tithonia $\left(20 \mathrm{~kg} \mathrm{P} \mathrm{ha}^{-1}\right)+\left(\right.$ TSP $\left.40 \mathrm{~kg} \mathrm{P} \mathrm{ha}^{-1}\right)$ & 17.4 & 15.8 & -1.6 & 8.9 & 8.6 & -0.3 \\
\hline (9) Tithonia (20 kg P ha-1) + BPR (40 kg P ha-1) & 12.4 & 12.6 & 0.2 & 4.4 & 5.1 & 0.7 \\
\hline (10) FYM (20 kg P ha-1) + MPR (40 kg P ha $\left.{ }^{-1}\right)$ & 15.0 & 15.7 & 0.7 & 7.4 & 9.3 & 1.9 \\
\hline (11) FYM (20 kg P ha $\left.{ }^{-1}\right)+$ TSP $\left(40 \mathrm{~kg} \mathrm{P} \mathrm{ha}^{-1}\right)$ & 14.5 & 17.7 & 3.2 & 8.0 & 6.0 & -2.0 \\
\hline (12) FYM (20 kg P ha-1) + BPR (40 kg P ha-1) & 13.1 & 16.1 & 3.0 & 5.9 & 5.8 & -0.1 \\
\hline (13) Tithonia $\left(20 \mathrm{~kg} \mathrm{P} \mathrm{ha}^{-1}\right)$ & 11.2 & 13.9 & 2.7 & 4.6 & 7.3 & 2.7 \\
\hline (14) FYM (20 kg P ha-1) & 12.7 & 15.6 & 2.9 & 5.7 & 7.5 & 1.8 \\
\hline (15) MPR (40 kg P ha-1) & 12.5 & 14.9 & 2.4 & 6.3 & 6.6 & 0.3 \\
\hline (16) TSP (40 kg P ha-1) & 14.2 & 16.6 & 2.4 & 6.7 & 7.3 & 0.6 \\
\hline (17) BPR $\left(40 \mathrm{~kg} \mathrm{P} \mathrm{ha}^{-1}\right)$ & 9.8 & 9.6 & -0.2 & 4.4 & 5.6 & 1.2 \\
\hline SED & 0.9 & 1.3 & & 0.7 & 0.7 & \\
\hline $\mathrm{CV} \%$ & 9 & 11 & & 10 & 10 & \\
\hline
\end{tabular}

WAI: weeks after incubation; FYM: farmyard manure; TSP: triple superphosphate; MPR: Minjingu phosphate rock;

BPR: Busumbu phosphate rock; SED: standard error of difference between means.

2.4. Effect of Phosphorus Sources on the Olsen Phosphorus in Soils. All the applied inputs generally increased the Olsen $\mathrm{P}$ levels compared with the control for both soil types at 4 WAI (Table 6). The highest Olsen $\mathrm{P}$ values for both soil types, at both sampling periods, were obtained with TSP $\left(60 \mathrm{~kg} \mathrm{Pha}^{-1}\right)$. When applied alone at the same $\mathrm{P}$ rate of $60 \mathrm{~kg} \mathrm{Pha}^{-1}$, there were no significant differences in Olsen $\mathrm{P}$ between FYM and TSP, but the two P sources had significantly higher Olsen $\mathrm{P}$ levels than tithonia, MPR, and BPR for the Bukura soil at 4 WAI. A similar trend was also observed for the Kakamega soil. FYM gave slightly higher but non significant Olsen $\mathrm{P}$ levels compared to tithonia at a similar $\mathrm{P}$ application rate applied at $20 \mathrm{~kg} \mathrm{P} \mathrm{ha}^{-1}$. In general, at the same $\mathrm{P}$ rate, the effectiveness in increasing the available $\mathrm{P}$ among the inorganic sources followed the order, TSP > MPR > BPR, while among the OMs, FYM was more effective than tithonia.

The combined application of the OMs, that is, tithonia or FYM, with TSP or the PRs did not result in synergy, whereby the available $\mathrm{P}$ increased more than the sum of the increase from either of the $\mathrm{P}$ sources applied singly. This is illustrated in Figures 1, 2, 3, 4, 5 and 6 for the Bukura soil. In general, the expected increase in the available $\mathrm{P}$ due to the additive effects of applying the inorganic and organic $\mathrm{P}$ sources separately was always greater than the actual increase obtained by combining the inorganic and organic $\mathrm{P}$ sources, at the same total $\mathrm{P}$ application rate (Figures 1-6). Combined application of organic and inorganic $\mathrm{P}$ sources generally resulted in observed increases in Olsen $\mathrm{P}$ intermediate to those of sole applications of the organic or inorganic $\mathrm{P}$ sources (Figures 1-6).

\section{Discussion}

The application of both FYM and tithonia generally increased the soil $\mathrm{pH}$ at 4 WAI with tithonia-treated soils having a higher $\mathrm{pH}$ than the FYM-treated soils at this time. The soil $\mathrm{pH}$, however, declined by 16 WAI with tithonia-treated soils showing the highest $\mathrm{pH}$ reductions. The increase in soil $\mathrm{pH}$ due to application of OMs at $4 \mathrm{WAI}$ in this study is consistent with results reported by several other workers (e.g., $[15,16])$. The principal mechanisms involved in increasing soil $\mathrm{pH}$ by various types of OMs differ considerably and according to [17], and a broad distinction can be made between the mechanisms of undecomposed plant materials such as tithonia and humified materials such as FYM and composts. The initial increase in the soil $\mathrm{pH}$ by FYM in the present study can primarily be attributed to the high $\mathrm{pH}$ of FYM (7.7) at the time of its application. It may also partly be explained by proton $\left(\mathrm{H}^{+}\right)$exchange between the soil and the added manure $[18,19]$. During the initial decomposition of manures, prior to their collection, some formation of phenolic, humic-like material may have occurred [16]. It is these organic anions that consume protons from the soil, thus tending to raise the equilibrium $\mathrm{pH}$ [20]. Another mechanism that has been proposed to explain the increase in soil $\mathrm{pH}$ by such materials as FYM is the specific adsorption of humic material and/or organic acids (the products of decomposition of OMs) onto hydrous surfaces of $\mathrm{Al}$ and Fe oxides by ligand exchange with corresponding release of $\mathrm{OH}^{-}$as suggested by [21]. On the other hand, [15] attributed the soil $\mathrm{pH}$ changes observed with fresh materials, for example, tithonia, in an incubation study, mainly to 


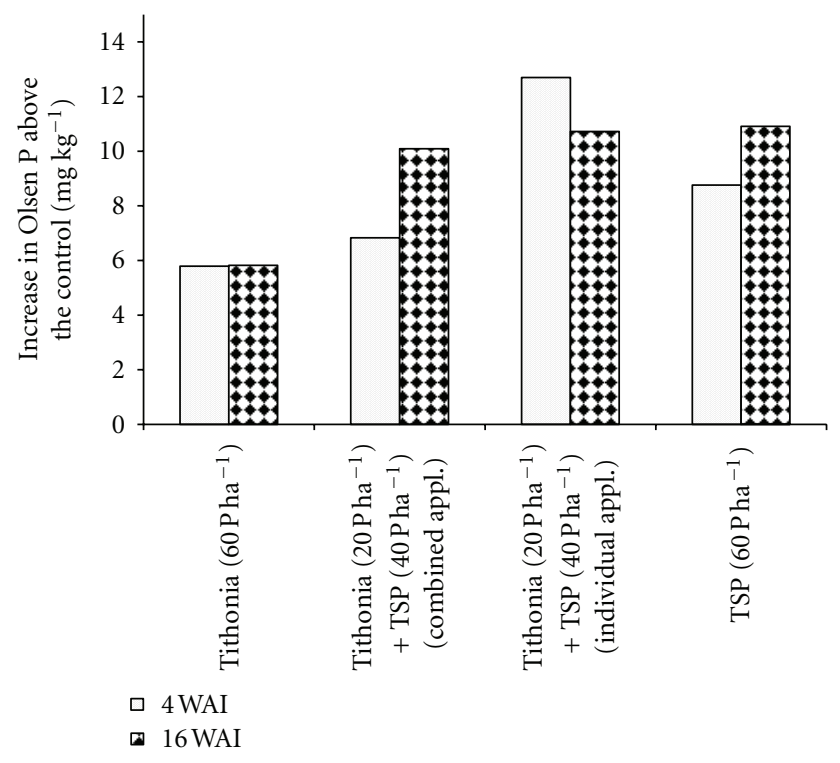

FIGURE 1: Increase in Olsen P above the control treatment as affected by tithonia and TSP at Bukura. Note: "combined appl." refers to the observed increase in Olsen $\mathrm{P}$ above the control obtained when tithonia (at $20 \mathrm{~kg} \mathrm{Pha}^{-1}$ ) was applied in combination with TSP (at $40 \mathrm{~kg} \mathrm{Pha}^{-1}$ ), while "individual appl." refers to the increase in Olsen $\mathrm{P}$ above the control obtained when tithonia, applied alone at $20 \mathrm{~kg} \mathrm{Pha}^{-1}$, was added to the increase in Olsen $\mathrm{P}$ above the control obtained when TSP was applied alone at $40 \mathrm{~kg} \mathrm{P} \mathrm{ha}^{-1}$.

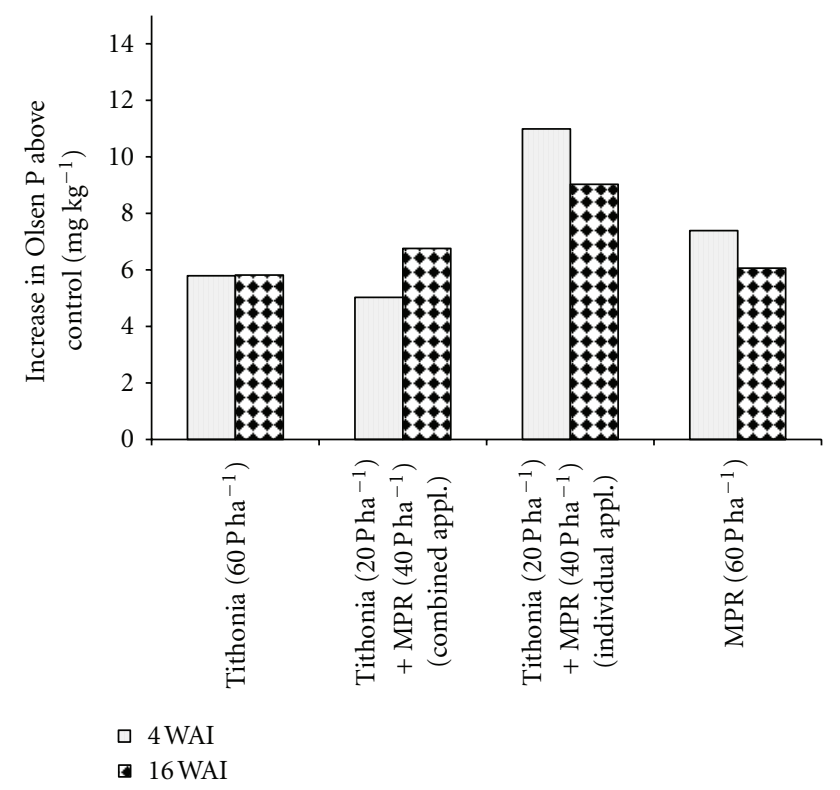

FIGURE 2: Increase in Olsen P above the control treatment as affected by tithonia and MPR at Bukura. Note: "combined appl." refers to the observed increase in Olsen $\mathrm{P}$ above the control obtained when tithonia (at $20 \mathrm{~kg} \mathrm{Pha}^{-1}$ ) was applied in combination with MPR (at $40 \mathrm{~kg} \mathrm{Pha}^{-1}$ ), while "individual appl." refers to the increase in Olsen $\mathrm{P}$ above the control obtained when tithonia, applied alone at $20 \mathrm{~kg} \mathrm{Pha}^{-1}$, was added to the increase in Olsen $\mathrm{P}$ above the control obtained when MPR was applied alone at $40 \mathrm{~kg} \mathrm{P} \mathrm{ha}^{-1}$.

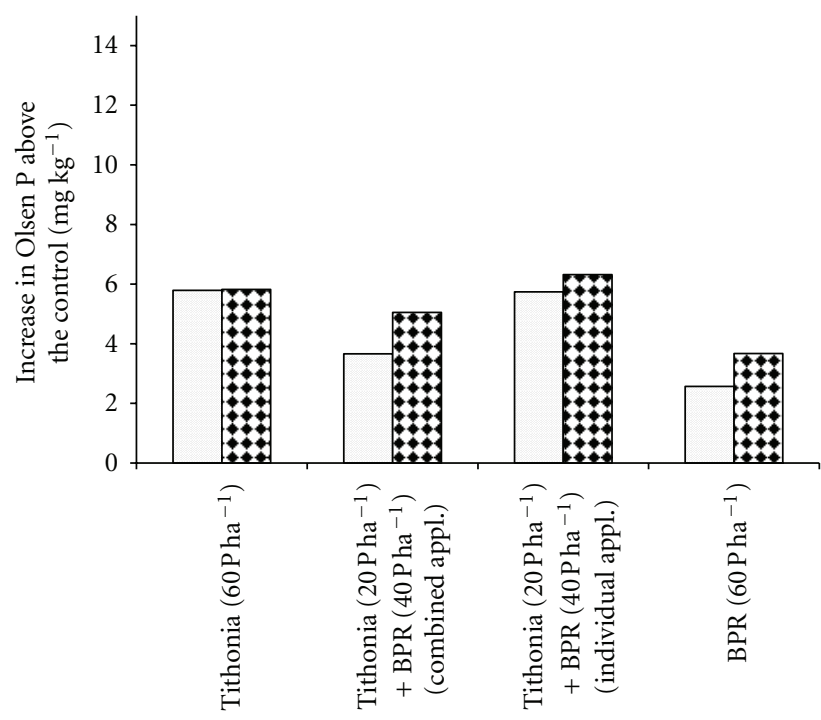

$\square$ 4WAI

- 16WAI

Figure 3: Increase in Olsen P above the control treatment as affected by tithonia and BPR at Bukura. Note: "combined appl." refers to the observed increase in Olsen $\mathrm{P}$ above the control obtained when tithonia (at $20 \mathrm{~kg} \mathrm{Pha}^{-1}$ ) was applied in combination with BPR (at $40 \mathrm{~kg} \mathrm{P} \mathrm{ha}^{-1}$ ), while "individual appl." refers to the increase in Olsen $\mathrm{P}$ above the control obtained when tithonia, applied alone at $20 \mathrm{~kg} \mathrm{P} \mathrm{ha}{ }^{-1}$, was added to the increase in Olsen $\mathrm{P}$ above the control obtained when BPR was applied alone at $40 \mathrm{~kg} \mathrm{Pha}^{-1}$.

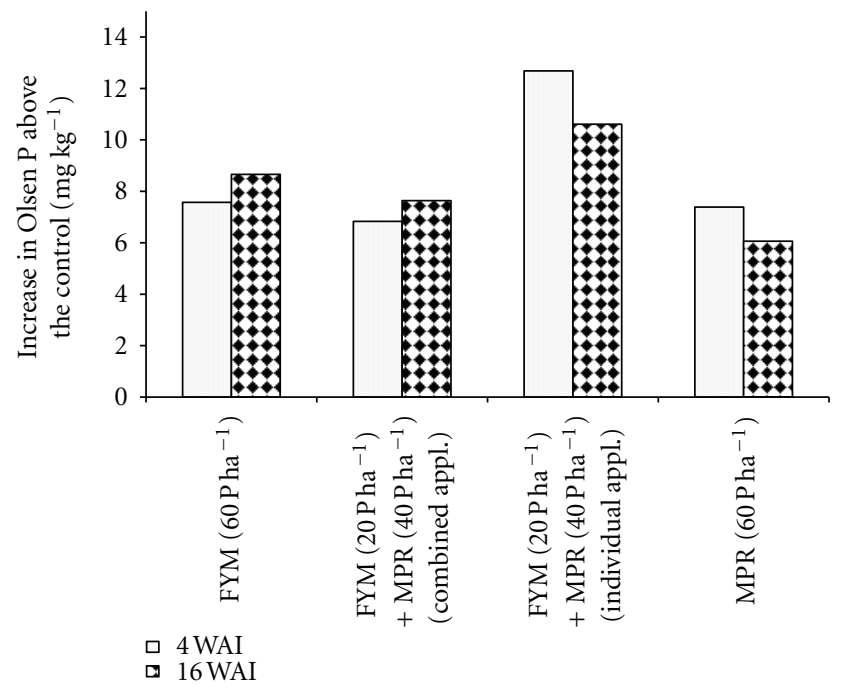

FIGURE 4: Increase in Olsen P above the control treatment as affected by FYM and MPR at Bukura. Note: "combined appl." refers to the observed increase in Olsen $\mathrm{P}$ above the control obtained when FYM (at $20 \mathrm{~kg} \mathrm{P} \mathrm{ha}{ }^{-1}$ ) was applied in combination with MPR (at $40 \mathrm{~kg} \mathrm{Pha}^{-1}$ ), while "individual appl." refers to the increase in Olsen $\mathrm{P}$ above the control obtained when FYM, applied alone at $20 \mathrm{~kg} \mathrm{P} \mathrm{ha}^{-1}$, was added to the increase in Olsen $\mathrm{P}$ above the control obtained when MPR was applied alone at $40 \mathrm{~kg} \mathrm{P} \mathrm{ha}^{-1}$. 


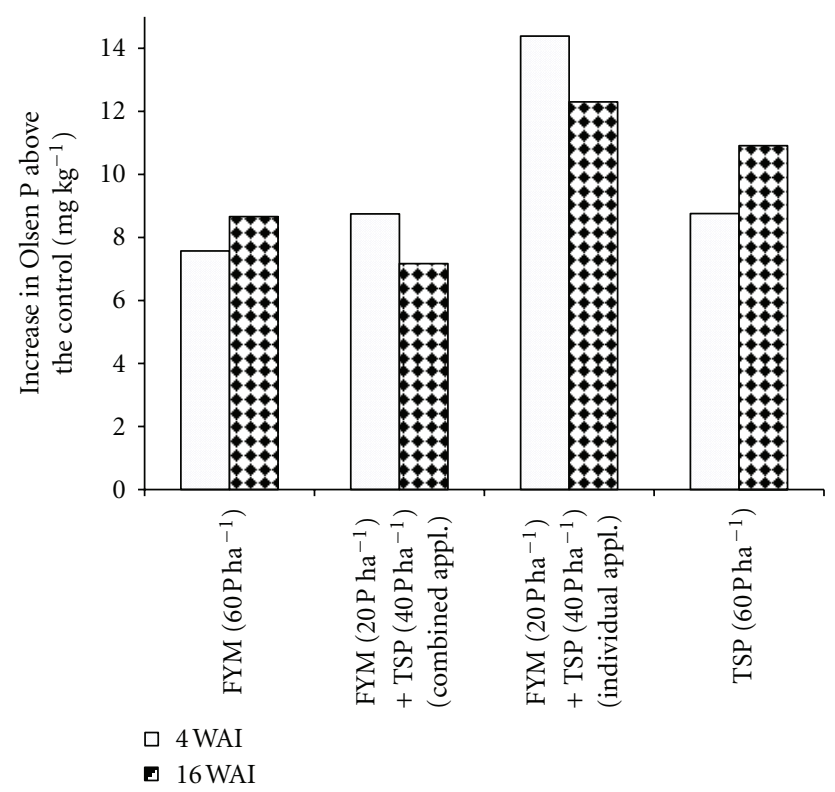

Figure 5: Increase in Olsen $\mathrm{P}$ above the control treatment as affected by FYM and TSP at Bukura. Note: "combined appl." refers to the observed increase in Olsen $\mathrm{P}$ above the control obtained when FYM (at $20 \mathrm{~kg} \mathrm{Pha}^{-1}$ ) was applied in combination with TSP (at $40 \mathrm{kgP} \mathrm{ha}^{-1}$ ), while "individual appl." refers to the increase in Olsen $\mathrm{P}$ above the control obtained when FYM, applied alone at $20 \mathrm{~kg} \mathrm{P} \mathrm{ha}^{-1}$, was added to the increase in Olsen P above the control obtained when TSP was applied alone at $40 \mathrm{~kg} \mathrm{P} \mathrm{ha}^{-1}$.

nitrogen transformations and release of metal cations as tithonia decomposed. In this incubation study, soils were amended with the OMs in a closed system without growing plants. Therefore, the effects of plant uptake, root exudates, and leaching are not relevant and the processes responsible for the $\mathrm{pH}$ changes are limited to the decomposition and nutrients held in tithonia and $\mathrm{N}$ transformations [15]. Under anaerobic conditions, $\mathrm{NH}_{4}{ }^{+}$produced by the ammonification process would accumulate due to inhibition of nitrification, and the $\mathrm{pH}$ would increase. However, under conditions favorable for microbial activity, such as those in the present study, the initial alkalization from plant residue amendment may be neutralized by subsequent nitrification, which is an acidifying process [22]. This is likely why there was a decline in soil $\mathrm{pH}$ in all the treatments by 16 WAI. The higher acidification observed for the tithonia-treated soils at 16 WAI in the incubation study is ascribed to its high nitrifiable $\mathrm{N}$ content $(3.3 \%)$ compared to the other treatments. Similar variations in soil $\mathrm{pH}$ with time, when different OMs were mixed with soil, were observed by [23]. The failure of the PRs to increase the $\mathrm{pH}$ is attributed to their low reactivity and low rates used.

3.1. Exchangeable Acidity and Exchangeable Aluminum. Addition of tithonia, FYM, and MPR had the effect of reducing both the exchangeable acidity and exchangeable $\mathrm{Al}$, but the magnitude of the reduction varied with each of these materials. Tithonia appeared to be more effective in reducing

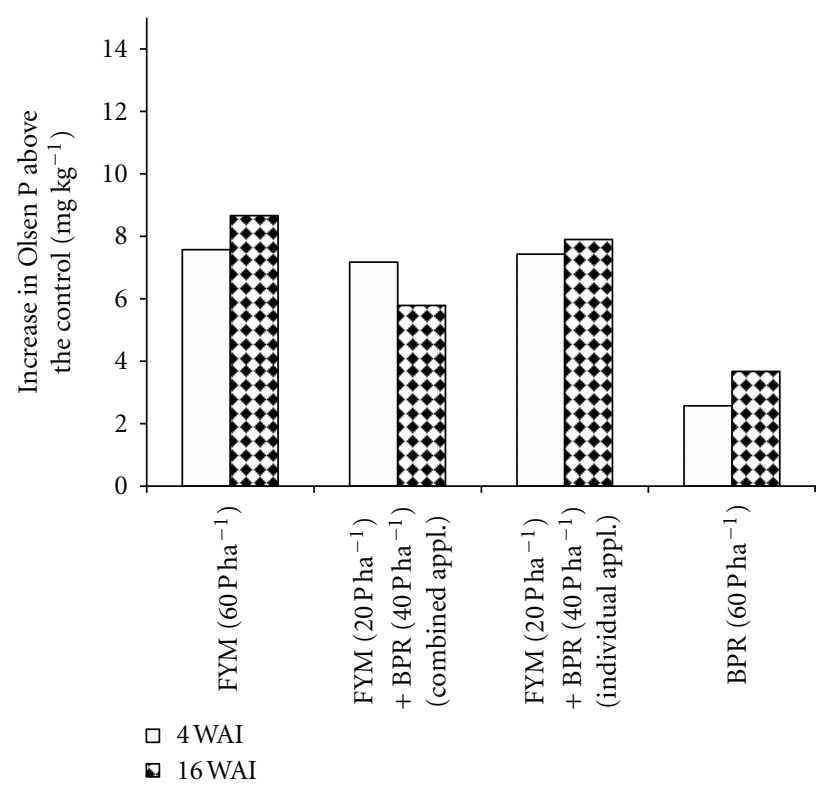

Figure 6: Increase in Olsen $P$ above the control treatment as affected by FYM and BPR at Bukura. Note: "combined appl." refers to the observed increase in Olsen $\mathrm{P}$ above the control obtained when FYM (at $20 \mathrm{~kg} \mathrm{P} \mathrm{ha}^{-1}$ ) was applied in combination with BPR (at $40 \mathrm{~kg} \mathrm{Pha}{ }^{-1}$ ), while "individual appl." refers to the increase in Olsen P above the control obtained when FYM, applied alone at $20 \mathrm{~kg} \mathrm{Pha}{ }^{-1}$, was added to the increase in Olsen $\mathrm{P}$ above the control obtained when BPR was applied alone at $40 \mathrm{~kg} \mathrm{Pha}^{-1}$.

exchangeable $\mathrm{Al}$, but not exchangeable acidity, compared to FYM. The reduction in exchangeable acidity can partially be attributed to an initial increase in soil $\mathrm{pH}$ that was observed with the OMs. Several other workers have measured an increase in soil $\mathrm{pH}$ with concomitant decrease in exchangeable Al during decomposition of organic residues in soils $[16,18,24]$. An increase in soil $\mathrm{pH}$ results in precipitation of exchangeable and soluble $\mathrm{Al}$ as insoluble $\mathrm{Al}$ hydroxides [25], thus reducing concentration of $\mathrm{Al}$ in soil solution. However, there are other mechanisms involved in the reactions of $\mathrm{Al}$ with OMs which are intricate and according to [25] probably involve complex formation with low-molecularweight organic acids, such as citric, oxalic, and malic acids, and humic material produced during the decomposition of the $\mathrm{OMs}$ and adsorption of $\mathrm{Al}$ onto the decomposing organic residues. Complexation by soluble organic matter may partially explain why the tithonia treatments were able to significantly reduce exchangeable acidity and $\mathrm{Al}$ relative to the control treatment, despite the fact that they had at times low $\mathrm{pH}$ that was comparable to that of TSP or BPR. Both TSP and BPR, however, failed to significantly reduce exchangeable $\mathrm{Al}$, likely due to their low content of $\mathrm{CaO}(19 \%$ and $35 \% \mathrm{CaO}$ for TSP and BPR, resp.).

The $\mathrm{Al}$ complexing effect of tithonia is likely to have been stronger than that of FYM given that FYM gave higher soil $\mathrm{pH}$ (5.17) than tithonia but still ended up with a higher level of exchangeable $\mathrm{Al}\left(0.35 \mathrm{cmol} \mathrm{kg}^{-1}\right)$. Tithonia was applied as a green manure and was thus likely to produce large 
quantities of organic acids, which would be involved in complexation reactions [3]. On the other hand, FYM had been exposed to the weather elements for a long time (one year) before its collection for use in this study. It was well rotten and hence likely to be at an advanced stage of decomposition and is therefore unlikely to have had substantial amounts of organic acids [3].

\subsection{Soil Olsen P Changes as Affected by Application of Organic} and Inorganic Inputs. Addition of P from both organic and inorganic sources generally resulted in increase in the Olsen $P$ relative to the control. The magnitude of the increase in the Olsen $\mathrm{P}$ depended on the soil type, time of soil sampling, $\mathrm{P}$ source, and rate of $\mathrm{P}$ application. On average, addition of $\mathrm{P}$ inputs generally resulted in larger increases in Olsen $\mathrm{P}$ for the Bukura soil than the Kakamega one. Similar site-specific differences in extractable soil $\mathrm{P}$, in response to applied $\mathrm{P}$ fertilizers, were found by [26]. The increase in the Olsen P with time of incubation contrasts with most studies which have reported a decline in the Olsen $\mathrm{P}$ with time, usually ascribed to $\mathrm{P}$ sorption by the soil (e.g., [27, 28]). However, a few studies $[29,30]$ have obtained results similar to those of the present study. These authors explained that the increase in $\mathrm{P}$ availability with time is likely due to microbially mediated mineralization of soil organic $\mathrm{P}$, to form inorganic $\mathrm{P}$ at a faster rate than that of $\mathrm{P}$ sorption by the soils of low to moderate $\mathrm{P}$ sorption capacity, such as those used in the current study. Also, due to the absence of plants in such incubation studies, the mineralized $\mathrm{P}$ is not taken up by plants and hence the observed increase in available $\mathrm{P}$ with time.

TSP gave the highest amount of Olsen $\mathrm{P}$ compared to the PRs, tithonia, or FYM, applied at the same total $\mathrm{P}$ rate at all times. This is ascribed to the higher solubility of TSP compared to the PRs whose dissolution is usually low and slow [31]. The OMs generally gave higher Olsen $P$ values than the PRs at comparable total $\mathrm{P}$ rates. This reflects the large percentage of soluble $\mathrm{P}$ in both the tithonia tissues and the FYM. High levels of water soluble $\mathrm{P}$ in plant tissues (50-80\%) have also been reported by [32]. Immediate net $\mathrm{P}$ mineralization would in addition be expected to occur because both OMs had a higher $\mathrm{P}$ concentration $(0.3 \%$ in tithonia and $0.4 \%$ in FYM) than the critical level of $0.25 \%$ required for net $\mathrm{P}$ mineralization [32].

The significant increase in Olsen $\mathrm{P}$ above the control by MPR indicates that the soil conditions at both sites were conducive to its dissolution. Some of the factors known to increase the dissolution and subsequent release of $\mathrm{P}$ in PRs include low soil $\mathrm{pH}$, low exchangeable $\mathrm{Ca}$, and low $\mathrm{P}$ [33]. The soils at both sites generally met these criteria. The higher amounts of Olsen $\mathrm{P}$ as a result of MPR application compared to BPR application can be attributed to differences in their solubility arising from varying extents of carbonate substitution in the PR [34]. Results of chemical analyses indicate that the BPR is a low-carbonate-substituted type of igneous origin. It has low reactivity in acid solvents with a neutral ammonium acetate (NAC) solubility of $2.3 \%$ compared to $5.6 \%$ of MPR [35].
The interaction between the OMs and inorganic $\mathrm{P}$ sources was significant only on a few occasions. In such instances, it was observed that combining the PRs with tithonia or FYM gave higher Olsen P values than when the PRs were combined with urea. However, when the TSP was combined with tithonia or FYM, it gave lower amounts of Olsen P than when it was combined with urea. This may suggest that tithonia and FYM were enhancing the dissolution of PRs, but retarding the availability of P from TSP. However, closer examination of the data reveals that tithonia and FYM were unlikely to have enhanced the dissolution of the PRs and that combining these two OMs with the PRs has no advantage in terms of increasing the Olsen $\mathrm{P}$ compared to their application with urea. There was therefore no synergistic effect in terms of increased Olsen P, when PRs were applied in combination with organic materials. In general, the combined application of organic and inorganic $\mathrm{P}$ sources generally resulted in observed increases in Olsen P intermediate to those of sole applications of the organic or inorganic $\mathrm{P}$ sources.

The likely reason why the PRs when combined with tithonia and FYM gave higher Olsen P levels compared to their combination with urea is because both tithonia and FYM were generally more effective in increasing the Olsen $\mathrm{P}$ compared to the PRs, and therefore, a portion of the insoluble PRs ( $\left.20 \mathrm{~kg} \mathrm{Pha}^{-1}\right)$ was substituted for by the more available tithonia or FYM in the combinations. However, when combined with urea all the $60 \mathrm{~kg} \mathrm{Pha}^{-1}$ was from the low soluble PRs and thus the lower Olsen P levels. On the other hand, TSP when combined with urea, gave higher Olsen P levels compared to its combination with tithonia or FYM. In this case, TSP was more effective in increasing the Olsen P compared to tithonia and FYM whose P is mostly in organic forms initially, and hence, substituting a portion of it $\left(20 \mathrm{~kg} \mathrm{Pha}^{-1}\right)$ in the combination with tithonia or FYM yielded less Olsen P than when it (TSP) was applied at the full rate of $60 \mathrm{~kg} \mathrm{P} \mathrm{ha}^{-1}$ with urea.

The findings of the present study are in contrast to others (e.g., $[2,4,36])$ who reported synergism when OMs such as manures were combined with PRs. These authors combined PRs with OMs of diverse composition and concluded that due to acidifying effect organic acids produced during the decomposition of the OMs, the solubilization of PRs was enhanced thus leading to the higher extractable $\mathrm{P}$ values in treatments where PR was combined with OMs than from application of PR alone. The most probable reason, however, why the combined application of PR and OM gave higher extractable $\mathrm{P}$ values compared to sole application of PR in these studies was because the contribution of $\mathrm{P}$ by the $\mathrm{OM}$ in the $\mathrm{OM} / \mathrm{PR}$ combination was not considered, thus leading to a higher total $\mathrm{P}$ rate in the $\mathrm{OM} / \mathrm{PR}$ combination than the sole $\mathrm{PR}$ application, and hence the higher amounts of available $\mathrm{P}$ in the combination. The results reported herein are, however, in agreement with other recent works where total $\mathrm{P}$ among the treatments to be compared was the same $[1,3]$. The common conclusion in these studies was that combination of PR with OMs does not enhance the dissolution of the $\mathrm{PR}$ mainly because OMs can increase the soil $\mathrm{pH}$ and $\mathrm{Ca}$ levels which are negatively correlated with $\mathrm{PR}$ dissolution. If the cost was not a limiting factor, then replenishing soil $\mathrm{P}$ 
using TSP would be a more appropriate strategy, as it results in more available $\mathrm{P}$ than when it is applied in combination with tithonia or FYM (at the same total P rate). Likewise, if availability and cost were not a constraint, then it would be better to apply tithonia or FYM alone at $60 \mathrm{~kg} \mathrm{Pha}^{-1}$ than combining them with MPR or BPR because the combination results in a lesser amount of available soil $\mathrm{P}$ than if the OMs are applied alone.

\section{Conclusion}

Tithonia and farmyard manure were more effective in increasing the soil $\mathrm{pH}$ and reducing exchangeable acidity and Al than the inorganic P sources (MPR, BPR, and TSP) in the early stages of incubation suggesting that these OMs can substitute for lime. Addition of $\mathrm{P}$ from both organic and inorganic sources generally resulted in an increase in the Olsen $\mathrm{P}$, relative to the control, whose magnitude depended on the soil type, time of soil sampling, $\mathrm{P}$ source, and rate of $\mathrm{P}$ application. The effectiveness of the inorganic $\mathrm{P}$ sources in increasing $\mathrm{P}$ availability followed the order, TSP > MPR > BPR, while among the OMs, FYM was more effective than tithonia. There was no synergistic effect, in terms of increased Olsen $\mathrm{P}$, when inorganic $\mathrm{P}$ sources were applied in combination with OMs. In general, the combined application of organic and inorganic $\mathrm{P}$ sources resulted in observed increases in Olsen $\mathrm{P}$ intermediate to those of sole applications of the organic or inorganic $\mathrm{P}$ sources. The combination of OMs with inorganic P fertilizers may, however, have other benefits associated with integrated soil fertility management.

\section{Acknowledgments}

The authors thank Moi University for financial assistance and for providing laboratory facilities, Mary Emong'ole for conducting laboratory analyses, and Laban Mulunda of Bukura Agricultural College for assistance with collection and preparation of the soil samples.

\section{References}

[1] P. Smithson, "Special issue on phosphorus availability, uptake and cycling in tropical agroforestry," Agroforestry Forum, vol. 9, no. 4, pp. 37-40, 1999.

[2] M. W. Waigwa, C. O. Othieno, and J. R. Okalebo, "Phosphorus availability as affected by the application of phosphate rock combined with organic materials to acid soils in western Kenya," Experimental Agriculture, vol. 39, no. 4, pp. 395-407, 2003.

[3] S. T. Ikerra, E. Semu, and J. P. Mrema, "Combining Tithonia diversifolia and minjingu phosphate rock for improvement of $\mathrm{P}$ availability and maize grain yields on a chromic acrisol in Morogoro, Tanzania," Nutrient Cycling in Agroecosystems, vol. 76, no. 2-3, pp. 249-260, 2006.

[4] M. N. Kifuko, C. O. Othieno, J. R. Okalebo, L. N. Kimenye, K. W. Ndung'u, and A. K. Kipkoech, "Effect of combining organic residues with Minjingu phosphate rock on sorption and availability of phosphorus and maize production in acid soils of western Kenya," Experimental Agriculture, vol. 43, no. 1, pp. 51-66, 2007.

[5] M. O. Anetor and E. A. Akinrinde, "Lime effectiveness of some fertilizers in a tropical acid alfisol," Journal of Central European Agriculture, vol. 8, no. 1, pp. 17-24, 2007.

[6] P. van Straaten, Rocks for Crops: Agrominerals of Sub-Saharan Africa, ICRAF, Nairobi, Kenya, 2002.

[7] P. Woomer, J. R. Okalebo, and P. A. Sanchez, "Phosphorus replenishment in western Kenya: from field experimentation to operational strategy," African Crop Science Journal, vol. 3, pp. 559-570, 1997.

[8] R. G. Menon, S. H. Chien, and A. E. N. Gadalla, "Phosphate rocks compacted with superphosphates vs. partially acidulated rocks for bean and rice," Soil Science Society of America Journal, vol. 55, no. 5, pp. 1480-1484, 1991.

[9] G. Nziguheba, "Overcoming phosphorus deficiency in soils of. Eastern Africa: recent advances and challenges," in Advances in Integrated Soil Fertility Management in Sub-Saharan Africa: Challenges and Opportunities, A. Bationo, Ed., pp. 49-160, Springer, Amsterdam, The Netherlands, 2007.

[10] B. B. Singh and J. P. Jones, "Phosphorous sorption and desorption characteristics of soil as affected by organic residues," Soil Science Society of America Journal, vol. 40, no. 3, pp. 389-394, 1976.

[11] J. M. Anderson and J. S. I. Ingram, Tropical Soil Biology and Fertility: A Handbook of Methods, CAB International, Wallingford, UK, 2nd edition, 1993.

[12] S. R. Nelson and and L. E. Sommers, "Organic carbon," in Methods of Soil Analysis, Part 2: Chemical and Microbiological Properties, A. L. Page, Ed., ASA-SSSA, Madison, Wis, USA, 2nd edition, 1982.

[13] J. R. Okalebo, K. W. Gathua, and P. L. Woomer, Laboratory Methods of Soil and Plant Analysis. A Working Manual, TSBF and SACRED Africa, Nairobi, Kenya, 2nd edition, 2002.

[14] C. A. Palm, C. N. Gachengo, R. J. Delve, G. Cadisch, and K. E. Giller, "Organic inputs for soil fertility management in tropical agroecosystems: application of an organic resource database," Agriculture, Ecosystems and Environment, vol. 83, no. 1-2, pp. 27-42, 2001.

[15] P. T. Cong and R. Merckx, "Improving phosphorus availability in two upland soils of Vietnam using shape Tithonia diversifolia H," Plant and Soil, vol. 269, no. 1-2, pp. 11-23, 2005.

[16] F. X. Narambuye and R. J. Haynes, "Effect of organic amendments on soil $\mathrm{Ph}$ and aL solubility and use of laboratory indices to predict their liming effect," Soil Science, vol. 17110, no. 10, pp. 754-763, 2006.

[17] M. T. F. Wong and R. S. Swift, "Amelioration of aluminium phytoxicity with organic matter," in Plant-Soil Interactions at Low pH: Principles and Management, R. A. Date, N. J. Grundon, G. E. Rayment, and M. E. Probert, Eds., pp. 41-45, Kluwer, Dordrecht, The Netherlands, 1995.

[18] M. T. F. Wong, S. Nortcliff, and R. S. Swift, "Method for determining the acid ameliorating capacity of plant residue compost, urban waste compost, farmyard manure, and peat applied to tropical soils," Communications in Soil Science and Plant Analysis, vol. 29, no. 19-20, pp. 2927-2937, 1998.

[19] C. Tang, G. P. Sparling, C. D. A. McLay, and C. Raphael, "Effect of short-term legume residue decomposition on soil acidity," Australian Journal of Soil Research, vol. 37, no. 3, pp. 561-573, 1999.

[20] R. J. Haynes and M. S. Mokolobate, "Amelioration of Al toxicity and $\mathrm{P}$ deficiency in acid soils by additions of organic residues: a critical review of the phenomenon and the 
mechanisms involved," Nutrient Cycling in Agroecosystems, vol. 59, no. 1, pp. 47-63, 2001.

[21] N. V. Hue, G. R. Craddock, and F. Adams, "Effects of organic acids on aluminum toxicity in subsoil," Soil Science Society of America Journal, vol. 25, pp. 3291-3303, 1986.

[22] K. I. Paul, A. S. Black, and M. K. Conyers, "Effect of plant residue return on the development of surface soil $\mathrm{pH}$ gradients," Biology and Fertility of Soils, vol. 33, no. 1, pp. 75-82, 2001.

[23] P. B. Hoyt and R. C. Turner, "Effects of organic materials added to very acid soils on $\mathrm{pH}$, aluminum, exchangeable $\mathrm{Nh} 4$, and crop yields," Soil Science, vol. 119, pp. 227-237, 1975.

[24] A. D. Noble, I. Zenneck, and P. J. Randall, "Leaf litter ash alkalinity and neutralisation of soil acidity," Plant and Soil, vol. 179, no. 2, pp. 293-302, 1996.

[25] G. S. P. Ritchie, "Role of dissolution and precipitation of minerals in controlling soluble aluminum in acidic soils," Advances in Agronomy, vol. 53, pp. 47-83, 1994.

[26] P. van der Zaag, R. L. Fox, R. De la Pena et al., Tropical Agriculture, vol. 56, pp. 155-160, 1979.

[27] E. C. Sample, R. J. Soper, and G. J. Racz, "Reactions of phosphate fertilizers in soils," in The Role of Phosphorus in Agriculture, F. E. Khasawneh, C. R. Dinauer, E. C. Sample, and E. J. Kamprath, Eds., pp. 263-310, American Society of Agronomy, Madison, Wis, USA, 1980.

[28] A. N. Sharply, "Effect of soil properties on the kinetics of phosphorus desorption," Soil Science Society of America Journal, vol. 47, pp. 462-467, 1983.

[29] C. A. M. Laboski and J. A. Lamb, "Changes in soil test phosphorus concentration after application of manure or fertilizer," Soil Science Society of America Journal, vol. 67, no. 2, pp. 544-554, 2003.

[30] E. Spychaj-Fabisiak, J. Długosz, and R. Zamorski, "The effect of the phosphorus dosage and incubation time on the process of retarding available phosphorus forms in a sandy soil," Polish Journal of Soil Science, vol. 38, no. 1, pp. 23-30, 2005.

[31] Mackay, A. D. Syers, and P. E. H. Greig, "A glasshouse comparison of 6 phosphate fertilisers," New Zealand Journal of Experimental Agriculture, vol. 12, no. 2, pp. 131-140, 1984.

[32] G. Nziguheba, C. A. Palm, R. J. Buresh, and P. C. Smithson, "Soil phosphorus fractions and adsorption as affected by organic and inorganic sources," Plant and Soil, vol. 198, no. 2, pp. 159-168, 1998.

[33] S. S. S. Rajan, J. H. Watkinson, and G. A. Sinclair, "Phosphate rock for direct application to soils," Advances in Agronomy, vol. 57, pp. 78-159, 1996.

[34] D. L. Anderson, W. R. Kussow, and R. B. Corey, "Phosphate rock dissolution in soil: indications from plant growth studies," Soil Science Society of America Journal, vol. 49, no. 4, pp. 918-925, 1985.

[35] S. J. Van Kauwenbergh, "Overview of phosphate deposits in East and Southeast Africa," Fertilizer Research, vol. 30, no. 2-3, pp. 127-150, 1991.

[36] D. D. Reddy, "Phosphorus solubilization from low-grade rock phosphates in the presence of decomposing soybean leaf litter," Communications in Soil Science and Plant Analysis, vol. 38, no. 1-2, pp. 283-291, 2007. 


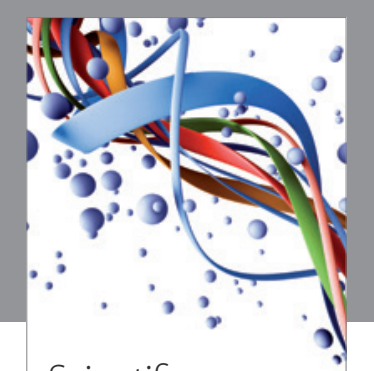

Scientifica
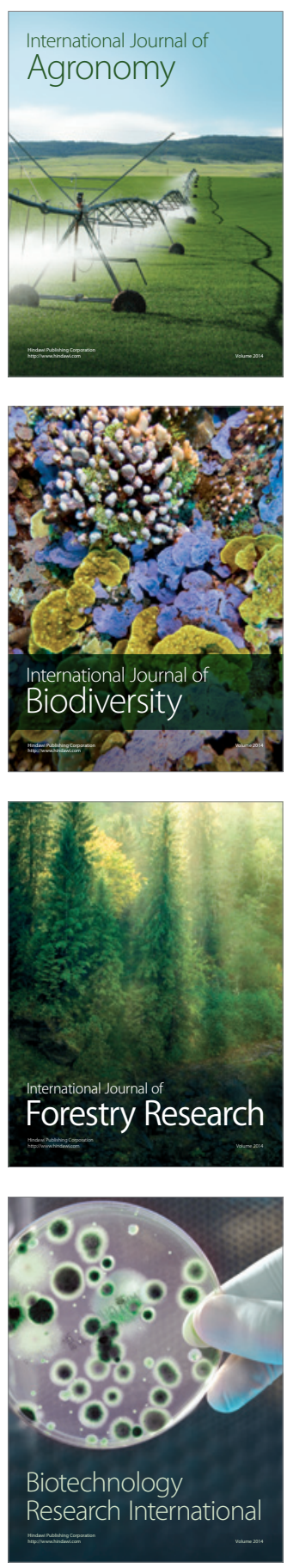
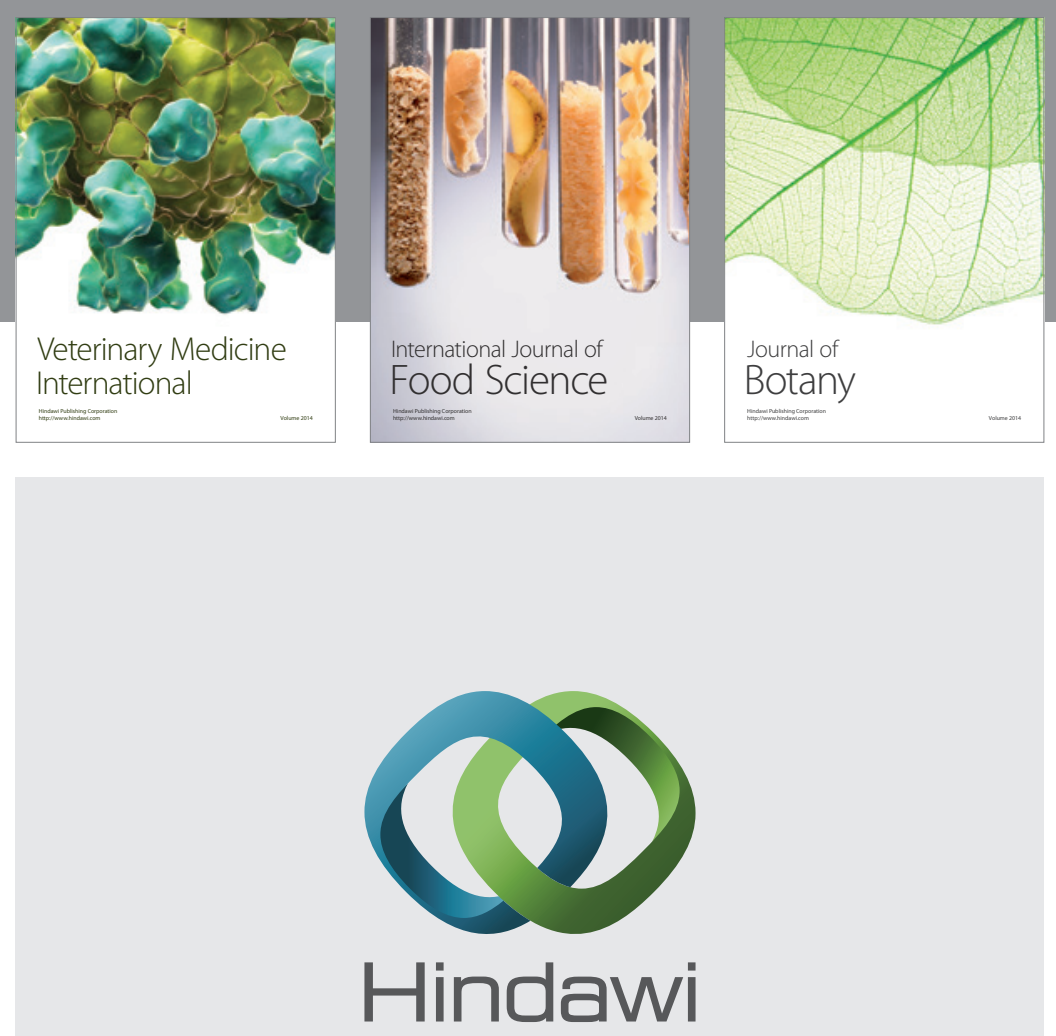

Submit your manuscripts at

http://www.hindawi.com
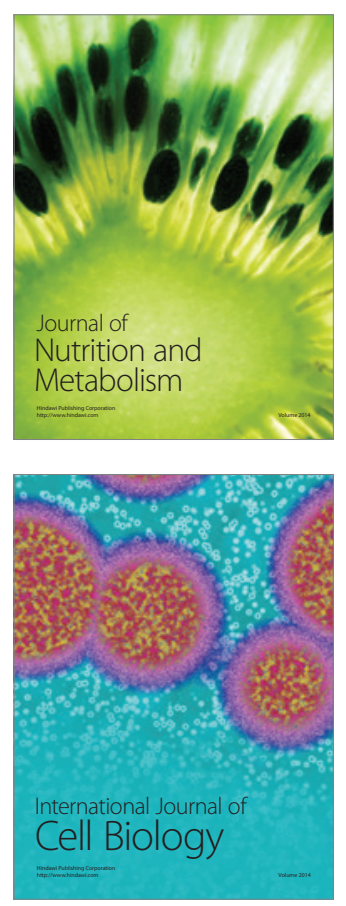
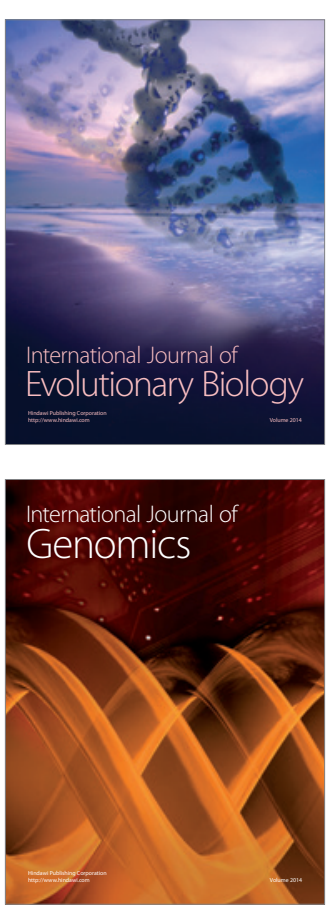
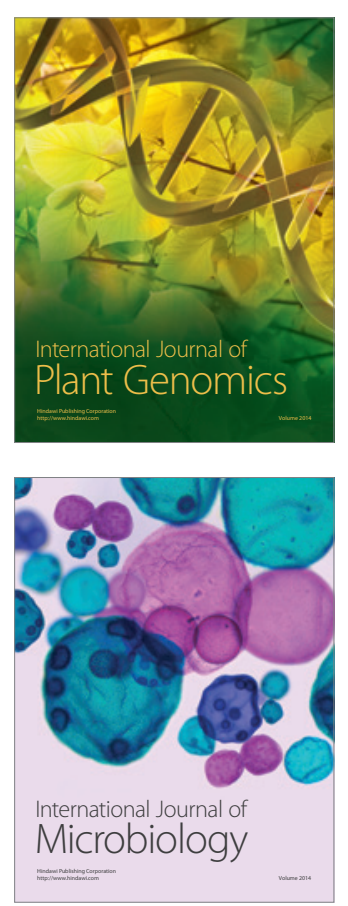

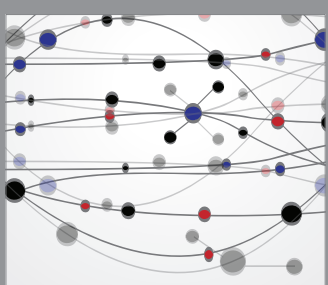

The Scientific World Journal
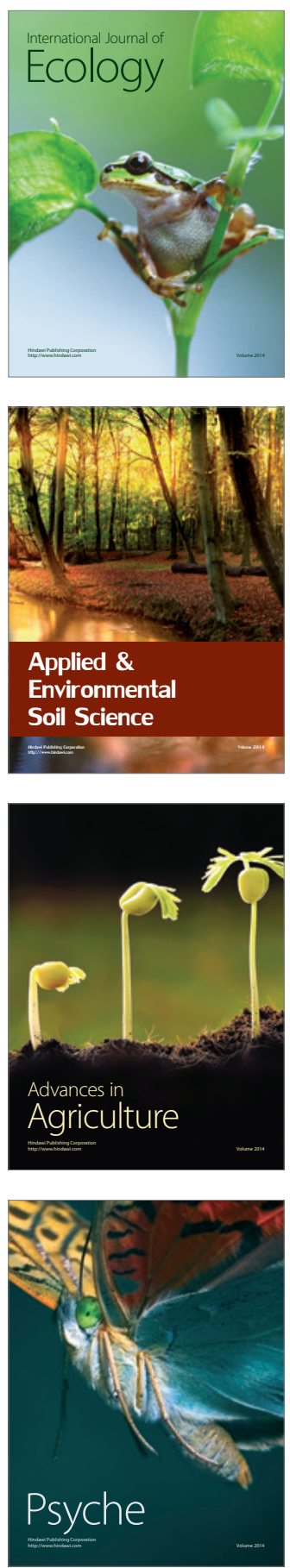